\title{
RESENHA
}

\section{A TRANSGRESSÃO DE VICENTE: RESENHA CRÍTICA DO CONTO "VICENTE"}

Josiane Müller ${ }^{1}$

MULLER, J. A transgressão de Vicente: resenha crítica do conto "Vicente". Akrópolis Umuarama, v. 28, n. 1, p. 95-97, jan./jun. 2020.

DOI: 10.25110/akropolis.v28i1.7933

Neste mundo contemporâneo são notáveis os contextos sociais que emergem, se desdobram, produzem e transformam, evidenciando as novas demandas no processo da construção de um ser social e os obstáculos nos ambientes educacionais, abrangendo as diversas práticas. Alves (1988) compara os educadores como as velhas árvores, possuem uma face, um nome, uma 'estória' a ser contada. Nisso, o conto Vicente (In: Bichos, 1984), de Miguel Torga, dialoga nessa visão de ter uma face, um nome e uma 'estória'.

$\mathrm{Na}$ possibilidade de uma interação dialógica na qual todos têm voz e vez, na base de toda a teoria bakhtiana, nos

'Universidade de Passo Fundo. Professora, Revisora e Designer Educacional. Editora Livrologia. Especialista em Orientação Educacional (UNIDEAU-RS) e em Linguagens e Tecnologias na Educação (IFSUL-RS). Mestranda do Programa de Pós-Graduação em Letras (UPF-RS). Bolsista Institucional UPF. josianemllr@gmail.com
Recebido em fevereiro de 2020 Aceito em abril de 2020 brota uma questão importante que é a presença do conceito de dialogismo no conto? Dessa forma, justificando a importância do Vicente, na relação dialética, sendo um corvo negro que simboliza a insubmissão, não aceita as imposições de Noé, nem de Deus, escolhendo a liberdade, mesmo sabendo que correria possíveis riscos de vida. Ele contrapõe-se a Noé, que aceita a submissão para reunir os bichos na arca, seguindo as ordens do Senhor, podendo, ainda, observar marcas de carnavalização, já que o personagem principal desmistifica vaidades e belezas. Bakhtin intitula de "literatura carnavalizada aquela que direta ou indiretamente, através de diversos elos mediadores, sofreu influência de diferentes modalidades de folclore carnavalesco (antigo ou medieval)" (BAKHTIN, 2002, p.107).

$\mathrm{Na}$ base de toda a teoria bakhtiana está o conceito de dialogismo, todo o discurso em forma e sentido na possibilidade de diálogo, definido como o princípio constitutivo da linguagem, o que significa que toda linguagem, em qualquer campo, está impregnada por relações dialógicas (LUKIANCHUKI, 2001, p. 2). Em razão disso,

não se excluem umas às outras, mas dialogicamente intersectam-se de maneiras muito diferentes, com uma interanimação em uma variedade de formas. Nesse processo, ocorre a coexistência de contradições socioideológicas entre o presente e o passado; entre diferentes épocas do passado; entre diferentes grupos socioideológicos do presente; entre tendências, escolas, círculos e assim por diante, com o encontro e a disputa entre pontos de vista sociolinguísticos distintos. Estes 
podem estar justapostos, mutuamente suplementando ou contradizendose; algumas linguagens falham a se desenvolverem, algumas morrem, enquanto que outras florescem em linguagens autênticas. Dado o jogo vivo, a linguagem se encontra em um histórico e ininterrupto processo de tornar-se, formando socialmente novas linguagens (FIORIN, 1994, p. 17).

No conto nota-se a expressão do contexto apresentado, século $X X$, já que Torga, que é pseudônimo de Adolfo Correia da Rocha, faz tal escolha na devoção por iberismo (partido dos que aspiram à junção política de Portugal e Espanha) e pela planta rasteira Torga, uma planta que se agarra à rocha para sobreviver, sendo assim, o escritor é reconhecido pelas marcas fortes de natureza.

Com a leitura de Umberto Eco (1940) nota-se que se pode fazer várias leituras num texto, mas não todas do conto em questão, que intertextualiza a narrativa bíblica do Dilúvio, do livro Gênesis, narrando a partida do personagem Vicente da Arca de Noé. Esse ato demonstra a autonomia da criatura sobre o criador, revelando que, quanto maior a prepotência do Senhor, maior a revolta de Vicente. Porém, ao fim, o Deus severo dá lugar a um Deus libertador, permitindo a concretização do ideal de Vicente de ser livre, assim o texto fala o que fala, porém deve-se ficar atento aos silêncios/vozes subentendidas na narrativa, que traz a conquista do ideal do personagem.

Nessas construções e desconstruções do contexto, Vicente, duela contra a tirania de Deus, representando a todos os animais presentes na arca, sendo uma insubmissão positiva, numa suspensão da descrença, representando conflitos da realidade, nessa fronteira entre o eu e o outro, onde uma minoria apoia e a maioria é contra.

Enquanto Noé é visto como um homem fraco e submisso, diante de Deus forte, grande, imponente, terrível, Vicente é o símbolo da universal libertação. Apesar do corpo esguio e um pouco degradado, seu perfil era de vontade e impavidez. Todos os animais tiveram na alma a paz da humilhação vingada por meio do corajoso corvo Vicente. Observe o trecho:

Naquela tarde, à hora em que o céu se mostrava mais duro e mais sinistro,
Vicente abriu as asas negras e partiu. Quarenta dias eram já decorridos desde que, integrado na leva dos escolhidos, dera entrada na Arca. Mas desde o primeiro instante que todos viram que no seu espírito não havia paz. Calado e carrancudo, andava de cá para lá numa agitação contínua, como se aquele grande navio onde o Senhor guardara a vida fosse um ultraje à criação. Em semelhante balbúrdia - lobos e cordeiros irmanados no mesmo destino -, apenas a sua figura negra e seca se mantinha inconformada com o procedimento de Deus. Numa indignação silenciosa, perguntava: - a que propósito estavam os animais metidos na confusa questão da torre de Babel? (TORGA, 1984, p. 127).

Ainda, no conto há marcas temporais, como a cronologia de 40 dias, assim como a referência à marca histórica de 2235 a.C., época em que teria ocorrido o dilúvio bíblico. A narrativa é linear e inicia com o clímax imposto pela fuga de Vicente da arca, que Eco (1949, p. 41) chama de in media res. O narrador não participa da história, sendo assim heterodiegético, subjetivo e onisciente.

De um modo geral, é possível fazer analogias do não dito com o dito, das inferências da história bíblica como representação da represália que sofriam na época da ditadura salazarista em Portugal. Pode-se fazer essa relação, pois a obra foi escrita em 1940, em pleno Estado Novo, implantado pelo regime de Salazar. O conto Vicente é quase o grito de liberdade dos perseguidos pela censura dessa época.

Ainda há o contraponto com a Arca, quando Noé larga um pombo, já no conto há a partida de um corvo, somente do corvo, simplesmente resoluto a onipotência divina, com a vontade inabalável de ser livre. Ao final, quando ninguém mais se sentia vivo na Arca, o Senhor cede, preservando a criação genesíaca, a fim de libertar os corações frágeis dos seres eleitos e condenados, além do coração deliberado de Vicente, enfatizando a sua transgressão.

Para Bakhtin (1995), a língua é um fato social cuja existência se funda nas necessidades da comunicação. Podemos enfatizar a luta social que passa pela palavra, enfatizado em Vicente:

A verdadeira substância da língua não é 
constituída por um sistema abstrato de formas lingüísticas nem pela enunciação monológica isolada, nem pelo ato psicofisiológico de sua produção, mas pelo fenômeno social da interação verbal, realizada através da enunciação ou das enunciações (BAKHTIN, 1995, p. 123).

Na perspectiva dialógica que observa a diversidade de vozes, os diferentes discursos, as diversas compreensões de mundo, a expansão do acesso às informações e do conhecimento a partir de obras como "Vicente". A Educação tem de estabelecer diálogos com todos esses meios, a fim de contribuir na formação de indivíduos. Alves (1988) expõe que os educadores habitam um mundo em que o que vale é a relação que os liga aos alunos, sendo que cada aluno é uma 'entidade' sui generis, portador de um nome, também de uma 'estória', sofrendo tristezas e alimentando esperanças. E a educação é algo pra acontecer neste espaço invisível e denso, que se estabelece a dois. Espaço artesanal (ALVES, 1988, p.17). Todavia, todos podem ser um dia Vicente.

\section{REFERÊNCIAS}

ALVES, R. Conversas com quem gosta de ensinar. 2. ed. São Paulo: Cortez, 1988.

BAKHTIN, M. Marxismo e filosofia da linguagem. 7. ed. São Paulo: Hucitec, 1995.

BAKHTIN, M. Problemas da poética de Dostoievski. Trad. Paulo Bezerra. 3. ed. Rio de Janeiro: Forense Universitária, 2002.

ECO, U. Seis passeios pelos bosques da ficção. Tradução Hildegard feist. São Paulo: Companhia das Letras, 1994.

FIORIN J. (Org.). Dialogismo, polifonia, intertextualidade: em torno de Bakhtin. São Paulo: Edusp, 1994.

LUKIANCHUKI, C. Dialogismo: A linguagem verbal como exercício do social. Revista Sinergia, 2001.

TORGA, M. Vicente. In: TORGA, Miguel.

Bichos: contos. 14. ed. Coimbra editora: [s.n.], 1984, p. 127-134. 